\title{
Obituaries
}

\section{Alexander Macdougal Cooke}

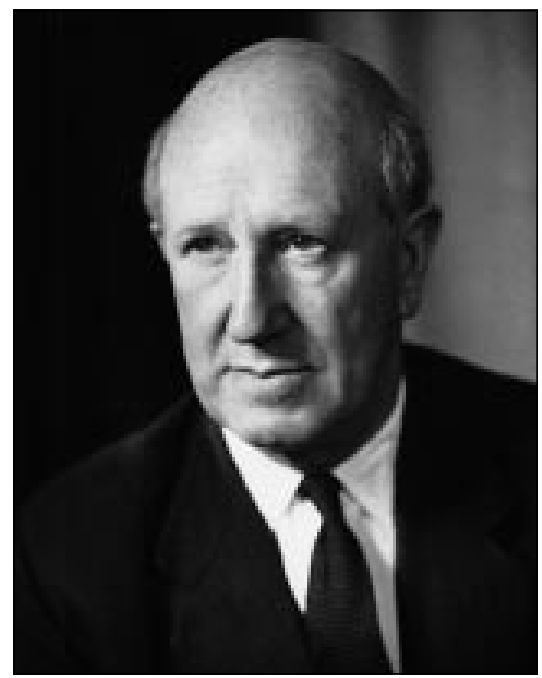

Former consultant physician Oxford $(b$ 1899; $q$ Oxford/St Thomas's 1923; MD, FRCP), $d 5$ January 1999. He went into the Royal Flying Corps in the first world war, but it ended just before he could start serious shooting. After qualifying he was appointed the only medical registrar at $\mathrm{St}$ Thomas's. He did not get the expected appointment; instead (a great stroke of luck he considered it) he was appointed to the Radcliffe Infirmary in 1932 where he remained. His appointments included director of medical students, examiner, counsellor, Lumleian lecturer, and fellow of Merton College. He was truly a general physician. When he started he was amazed to see cases of pernicious anaemia treated with half cooked liver and cases of diabetes receiving the new, impure, bulky (but life saving) insulin. He was an outstanding teacher, being particularly good at clinical demonstrations, which were remembered by the students for decades. His pithy sayings were famous-for example, "It costs more than you think"; "It takes longer than you think"; and, after he had had a wisdom tooth out, "a minor operation is an operation done on someone else." They are included in his 1994 publication My First 75 Years in Medicine. Alec Cooke had an effect on the whole physician community in innumerable ways, and as a result was one of the most revered and beloved physicians of our time. Predeceased by his wife, Vera, and a daughter, he leaves a son and two daughters. [David Pyke]

\section{James Rollo Ballantyne}

Former general practitioner Walton-onThames ( $b$ Nottingham 1917; q St Mary's 1942; DObstRCOG), d 30 December1998. A competent pianist, Rollo was cofounder of the Music Society at St Mary's and initiated a series of celebrity concerts; the pianist Solomon played 11 times in 15 years. He served in the Royal Army Medical Corps for over three years, and when he entered general practice he took an interest in obstetrics. He took pleasure in delivering the first baby of a woman whom he had also delivered. In 1971, stimulated by the work of his elder brother, David, a respected potter and teacher, he and his wife began to collect 20 th century ceramics. The Rollo and Marion Ballantyne collection is now housed at the Castle Museum in Nottingham. He continued to collect privately, but in 1995 most of his latter acquisitions were auctioned at Bonhams; they included what was described as "the finest private collection of Lucie Rie pots ever to come on the market." He leaves a wife, Marion; his first wife, Tym, and their three children; two grandchildren; and his triplet brother, John (a retired ear, nose, and throat surgeon). [JoHn BALLANTYNE]

\section{Roger Malcolm Richard Barnes}

Senior clinical lecturer University of Liverpool and honorary consultant immunologist Royal Liverpool University Hospital ( $b$ 1942; $q$ St Mary's 1966; PhD, FRCPath), died unexpectedly from a myocardial infarction on 22 December 1998. After training in London Roger moved to Liverpool in 1977 and was head of the department of immunology until 1996 and head of the clinical immunology service for over 21 years. He oversaw the establishment of the clinical and academic department within the newly established Royal Liverpool University Hospital in 1978, and saw the expansion in clinical service load. He was chairman of the Clinical Immunology Affinity Group of the British Society for Immunology from 1993, a member of the council of the British Society for Allergy and Clinical Immunology from1993-6, and specialty regional adviser in immunology for the Royal College of Pathologists from 1996. He latterly taught on the newly established MSc in human immunity. Roger was passionately interested in golf and opera. He leaves a wife, Annette, and a son and daughter. [Peter Johnson]

\section{Evan Fletcher}

Former consultant physician and cardiologist Belfast, 1948-70, and adviser Glaxo Group, 1978-87 ( $b$ Northern Ireland 1917; $q$ Queen's University Belfast 1939; MD, FRCP; OBE, QHP), d 14 October 1998. He served throughout the war, firstly, with the Royal Army Medical Corps and took part in the withdrawal from Dunkirk, and then with the Indian Medical Service in the North West Frontier and in Central Command. He had many publications; the best known was The Atlas of Cardiology. He worked at the University of Pennsylvania in 1955 and returned to the United States in 1971 as professor of cardiology at the University of Kentucky. Two years later he was appointed professor of medicine at the University of Texas and director of cardiology at the Texas Medical Centre in Houston. In 1978 he began a further career as adviser and then consultant in cardiovascular medicine to Glaxo, where he made valuable contributions to the development of several important drugs, including Zantac. He retained this appointment until his death. He never completely retired, but continued his education, teaching, gardening, and writing. He leaves a wife Dolores; a daughter and step daughter; three grandchildren; and one great grandchild. [Peter DAVIDSON]

\section{John Nigel Harcourt-Webster}

Former emeritus consultant histopathologist Chelsea and Westminster Hospital and Home Office pathologist ( $b$ Chesterfield 1930; $q$ Cambridge/St Thomas's 1954; MD, FRCPath), died from a stroke on 14 November 1998. Nigel came to St Stephen's Hospital (to be replaced by the Chelsea and Westminster) in 1970 where he found himself in the midst of administrative reorganisation-amalgamation of medical schools, changing boundaries, and the internal market. Nigel's personal qualities were valuable on the district management team and as chairman of the district medical committee. There was a danger of the hospital closing, but in 1989 the seeds were sown for the creation of a new hospital. Throughout this time Nigel had an open access policy in the separate pathology department building where any member of staff could access his advice, be it about a grievance or a matter of policy. With colleagues at the Institute of Neurology he researched the effects of AIDS on the nervous system and wrote many papers on AIDS and HIV. One result 
was the housing in St Stephen's of the largest unit for HIV disease in the United Kingdom. After retirement he became chairman of the Riverside Research Ethics Committee. For relaxation Nigel enjoyed opera, do-it-yourself, and European holidays where he could indulge in his fascination for trains and river cruises. $\mathrm{He}$ leaves a wife, Elizabeth; a daughter; and two sons. [Ariel Lant and Simon HarcourtWEBSTER]

\section{Samuel (“Stanley”) Leslie Isaacs}

Former general practitioner Merthyr Tydfil and London ( $b$ 1913; $q$ Welsh National School of Medicine 1935 (gold medal)), died from cerebral arterial disease on 7 December 1998. After his father died in the 1914 flu epidemic his mother made great sacrifices to educate her four children, two of whom became doctors and two pharmacists. It would have put the family to greater expense to specialise so Stanley set up a singlehanded practice in Merthyr, where a brother and cousin were known as "Isaacs the chemist." He quickly became "Isaacs the doctor," and was in such demand for house calls that he became the only GP in the town to have a chauffeur. He moved to Newport and then to Willesden where he maintained a substantial practice until forced to retire from the NHS on ill health grounds in 1966. He continued in private practice and served on medical boards. $\mathrm{He}$ was a delightful companion with an impish wit, and in his early days loved horse racing, was an excellent card player, and an accomplished ballroom dancer. He loved his religion and he was sad when he was unable to get to his beloved shul only a few yards from his home. He leaves a wife, Marquette, and two sons. [Norman PollitT AND ERIC FINE]

\section{Jack Joseph}

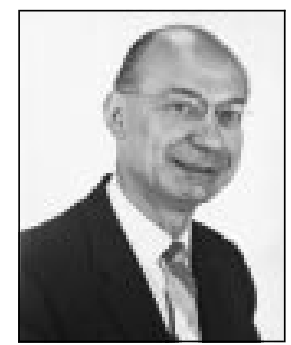

Professor of anatomy Guy's Hospital Medical School, 1965-80 ( $b$ 1913; $q$ Glasgow 1936; MD, FRCOG), died from colonic adenocarcinoma metastatic to the liver on 16 November 1998. Born into an immigrant Jewish family Jack spent his childhood in the Gorbals district of Glasgow where parents, six siblings, and a cousin shared a modest tenement flat. He was intent on becoming an obstetrician, but pulmonary tuberculosis prompted him to redirect his interests. He was enthusiastic and committed to teaching and research, but was less interested in committee work and internal politics. Despite his somewhat austere exterior, Jack was sensitive to the needs of those who found anatomy either taxing or uninteresting, and was pragmatic about its place in the training of doctors. He wrote specialist anatomical words and textbooks, the latter being known for the clarity and brevity of their presentation. He examined regularly and was aware of the potential for abuse of the examiner's position, regarding himself as a protector of weak candidates faced with an irascible coexaminer (in his experience, usually a surgeon). Jack was interested in the functional anatomy of the locomotor system and in particular the anatomy of posture and walking. Publications on the pattern of muscle activity in women walking on high heels pay equal tribute to his nose for an elegant scientific experiment and his understated sense of humour. He was also interested in aspects of wound healing and transplantation biology. Jack continued writing after retirement and published his last piece on anatomy of speech at the age of 80 as part of the 38th edition of Gray's Anatomy. He leaves a wife, Carol; four children (two by a previous marriage); and five grandchildren. [Mike Stratton]

\section{Sidney Levine}

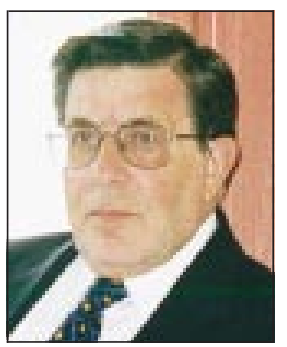

Former consultant psychiatrist Royal Oldham Hospital $(b$ 1932; $q$ Glasgow 1955; FRCPEd, FRCPsych), died after surgery for cholangiocarcinoma on 5 August 1998 . He had an international reputation as a lecturer in psychopharmacology and took part in many drug trials. He served on several of his college committees and was a council member for many years. He was a member of the special committee on the political abuse of psychiatry and negotiated with the government of the former Soviet Union. He wrote many papers on depression, anxiety, and schizophrenia, and after retirement he had an active medicolegal practice and was adviser to pharmaceutical companies. $\mathrm{He}$ had an outgoing personality, which made him a lively and entertaining companion. He leaves a wife, Leila; two daughters and a son; and three grandchildren. [NEville BERLYNe]

\section{John Stewart Mather}

Former general practitioner Romiley, Cheshire ( $b$ Bradford 1917; $q$ Leeds 1940), died from renal carcinoma on 17 November 1998. He served in the Royal Army Medical Corps in Northern Ireland, India, Burma, and Assam, where he became medical officer to the 2nd Battalion Royal Norfolks during the battle of Kohima against the Japanese. He was mentioned in dispatches for treating the wounded under fire. He took over the singlehanded practice in Romiley, and, with his wife, was the first doctor in the district to offer cervical cytology tests. His hobbies included cars, model engineering, and, to the astonishment of his patients, cross country running. He became a painter of considerable talent. Predeceased by one of his children, he leaves a wife, Maud (also a doctor), and three children (one a general practitioner). [ $\mathrm{R} \quad \mathrm{L}$ GADD AND MAUD MATHER]

\section{George Ranken Tudhope}

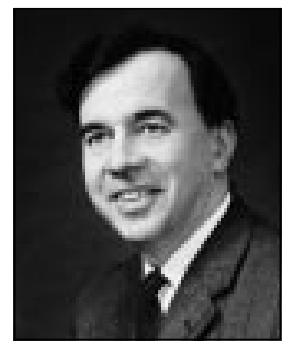

Former reader in therapeutics University of Dundee and honorary consultant physician Ninewells Hospital and the Royal Infirmary, Dundee ( $b$ 1924; $q$ St Andrews (Low Memorial Prize) 1947; MD (honours), FRCP), died from dementia on 24 July 1998 . His interest in haematology developed during a Medical Research Council travelling fellowship at the University of Utah in 1959-60. After academic appointments in Sheffield he returned to Dundee in 1964. In addition to research interests, involving catalase and other erythrocytic enzymes, he contributed to the development of radioisotopes in haematological investigations. He produced many publications and directed the Tayside Haemophilia Centre. He was a member of the Joint Formulary Committee for the British National Formulary and of the British Pharmacopoeia Commission. He leaves a wife, Jessie, and two sons. [John McEwen, Douglas Tudhope]

A service in memory of the life of Dr Susan Bellman, who died on 9 November 1998 (obituary: 31 January, p 333), will be held on Monday 15 March at Finchley Reform Synagogue, Fallowcourt Avenue, Finchley, London N12 at $230 \mathrm{pm}$. 